\title{
Verónica Valdivia Ortiz de Zárate, Rolando Álvarez Vallejos y Karen Donoso Fritz (Eds.), La alcaldización de la política. Los municipios en la dictadura pinochetista. Santiago de Chile: LOM Ediciones, 2012, 202 páginas.
}

\author{
Jorge Gaete*
}

La Dictadura de Augusto Pinochet, fue un período en el que se desarrollaron transformaciones estructurales en el país, las que tuvieron como gran meta la de erradicar la experiencia que representó, para sus integrantes y correligionarios, vivir bajo los parámetros que buscó imponer la Unidad Popular entre 1970 y 1973 . Hubo varios cambios, pero uno de los más interesantes fue la descentralización y la disminución de la influencia del Estado en la sociedad, para dar paso y protagonismo a los municipios y sus alcaldes, quienes dejaron la imagen lejana que antes tuvieron y emergieron como los principales representantes del régimen para solucionar las demandas existentes a nivel local.

Pues bien, he aquí el tema en el que se centra el presente libro, en cuyos cuatro capítulos, escritos por Verónica Valdivia, Rolando Álvarez y Karen Donoso, se analiza el desarrollo de este proceso desde la instauración de la Junta militar y la ejecución del proyecto neoliberal, hasta las políticas que años después se implementaron para atenuar los altos índices de cesantía, enfrentar el déficit habitacional, e impulsar el fomento al deporte. Con todo esto, los autores se proponen mostrar, con ejemplos claros y contundentes, que la "alcaldización" fue una exitosa transformación política, al punto que al poder enfrentar las necesidades comunales, perduró más allá del retorno de la democracia, y sobrevive hasta el día de hoy. En el primer capítulo, luego de mencionar la importancia que hoy en día tienen las elecciones municipales, por ser bastiones sectoriales de los partidos políticos, Verónica Valdivia se remite al régimen militar y al replanteamiento que

\footnotetext{
* Estudiante del Programa de Magíster en Historia, Facultad de Humanidades y Educación, Universidad Andres Bello. Santiago, Chile. Correo electrónico: jlgaete_reload@hotmail.com
} 
tuvo la figura del alcalde para la administración comunal. Aquí resalta que, como el proyecto neoliberal buscó la "resocialización" y la despolitización de la mayor parte de la sociedad chilena, se buscó que ésta dejase de lado los temas macro para que dirigiese su atención en sus demandas locales, con lo que el municipio emergió como el organismo clave para la administración de tales demandas. También rescata los cambios institucionales vividos por el Estado que formaron la base para conocer y encauzar estas necesidades, destacándose la fusión de militares y tecnócratas, y el actuar de organismos como la Comisión nacional de Reforma Administrativa (CONARA) y la Secretaría General de Gobierno (SGG), los que fueron clave para legitimar el ideario neoliberal, y para llevar a cabo tales reestructuraciones.

A partir del segundo apartado del texto, los autores ponen énfasis en la pobreza que afectó a buena parte de la población, y en las problemáticas que a partir de este dilema surgieron, sobre todo bajo el contexto de la crisis de 1982. Aquí, Verónica Valdivia y Rolando Álvarez nos presentan un estudio que se enfoca en la cesantía y en los programas que el régimen buscó implementar para absorber mano de obra de manera temporal, y con salarios mínimos, destacando especialmente al Programa de Empleo Mínimo (PEM) y el Programa para Jefes de Hogar (POJH), los que entregaban en la época un salario básico de subsistencia, empleando a gente en labores como el aseo, en la construcción de jardines y plazas, entre otros. Junto con combatir estos dilemas, destacan que los planes laborales de la Dictadura apuntaron a desactivar el potencial crítico de la población y a implantar un discurso popular anticomunista. Posteriormente, el tercer escrito del libro, a cargo de Karen Donoso, se centra en el rol que tuvo la Dirección General de Deportes y Recreación (DIGEDER) como una institución impulsora de actividades deportivas y de esparcimiento, dentro de la política socio-cultural que buscó fomentar la Dictadura. Sobre esta, recalca que a través de la actividad física y de la recreación se propuso combatir la extrema pobreza, para infundir un estilo de vida sano y valores a los sectores desposeídos. Al mismo tiempo, a nivel comunal nos muestra que esta actividad permitió el surgimiento de nuevas formas de sociabilidad, como los clubes, organizaciones folclóricas y organismos afines. Más adelante, Rolando Álvarez expone en el cuarto capítulo la política habitacional de la Dictadura, la que tuvo por objeto el erradicar los campamentos y dar una solución habitacional a una gran parte de la población que vivía expuesta a precarias condiciones de vida. En esta sección nos muestra la manera en que 
se enfrentó el tema, así como las medidas que se llevaron a cabo para construir viviendas sociales y "casetas sanitarias" de urgencia para combatir los riesgos higiénicos a los que los pobres estaban expuestos, y de manera simultánea indica el dilema de los allegados, quienes formaron parte de la oleada de tomas de terreno de esos años, sobre todo en el sector sur de Santiago.

Con respecto a este dilema, y para concluir el autor le da una especial importancia a la ofensiva comunicacional del régimen, que sirvió para catapultar a Pinochet como el "general de los pobres", para potenciar a líderes carismáticos de la derecha en las poblaciones, y para quitar el arraigo popular que tuvo la izquierda en esos sectores. De esta manera, logra comprobar el éxito que tuvieron estas medidas para la derecha en general, como un capital político que se aseguró con el paso de los años.

De hecho, este último tema forma parte de las conclusiones del texto, sección en la que se reafirma la manera con la que la derecha penetró, a través de las políticas estudiadas en el libro, en en comunas pobres que históricamente fueron un electorado de izquierda. Con análisis estadísticos y cifras, muestran el crecimiento sostenido que tuvo en las elecciones que hubo luego de 1990, el que le permitió asegurar una alta cantidad de municipios para su sector.

El libro también incluye un apéndice con entrevistas a Patricia Díaz, Gladys Soto y a Cristián Gajardo, chilenos que vivieron en carne propia los beneficios entregados por la Dictadura. Este elemento se hace muy interesante de considerar, porque en sus relatos nos entregan su experiencia como cesantes y pobladores de campamentos, y como receptores de sus viviendas definitivas, con todas las luces y sombras que todo eso significó para sus vidas. No cabe duda el valor que esto posee al momento de enfrentar la historia reciente del país, corriente en la que la entrevista juega un papel fundamental al momento de aproximarse a los procesos a través de las distintas miradas de quienes lo vivieron.

En cuanto a La alcaldización de la política. Los municipios en la dictadura pinochetista, es necesario rescatar que es un libro que además del valor historiográfico que posee, al momento de estudiar las siempre complicadas últimas décadas de la historia de Chile, logra dar, de forma certera, con los orígenes de la estructura/ relación comunal municipio-persona en la que muchos chilenos hoy en día viven y dependen. Sería muy interesante ver la manera en que este proceso se desencadenó en esos años en las otras regiones del país, pero definitivamente el libro explica de muy buena manera la magnitud que tuvo el fenómeno, y representa un primer gran paso para los futuros estudios que se realizarán. 